\title{
Pemetaan Kemiskinan di Kabupaten Mukomuko Menggunakan Small Area Estimation dengan Pendekatan Regresi Penalized Spline
}

\author{
Idhia Sriliana ${ }^{1)}$, Dian Agustina ${ }^{2)}$, Etis Sunandi ${ }^{3)}$ \\ 1,2,3)Program Studi Statistika Fakultas Matematika dan Ilmu Pengetahuan Alam \\ Universitas Bengkulu \\ email: idhiasriliana@unib.ac.id ${ }^{1)}$
}

\begin{abstract}
Abstrak
Penelitian ini bertujuan untuk melakukan pemetaan kemiskinan di Kabupaten Mukomuko Provinsi Bengkulu. Metode yang digunakan dalam penelitian ini adalah small area estimation (SAE) dengan pendekatan regresi penalized spline (P-Spline). Pendugaan parameter model dasar SAE umumnya membangun suatu model linear campuran yang mengasumsikan bahwa variabel respon dan variabel prediktor mempunyai hubungan linier. Ketika asumsi tersebut tidak terpenuhi, maka dilakukan pendekatan nonparametrik sebagai alternatif pilihan. Salah satunya adalah pendekatan nonparametrik P-Spline. Pada penelitian ini, dilakukan pendugaan parameter model menggunakan P-Spline sehingga diperoleh suatu persamaan regresi efek campuran sebagai model SAE. Selanjutnya model tersebut digunakan untuk menduga tingkat kemiskinan pada area yang tersampling sehingga diperoleh penduga tingkat kemiskinan pada level desa di Kabupaten Mukomuko yang disajikan dalam bentuk peta kemiskinan. Hasil penelitian menunjukkan pendugaan menggunakan model SAE dengan P-Spline memiliki trend (kecenderungan) yang sama dengan penduga langsung. Kecamatan yang memiliki tingkat kemiskinan tinggi menyebar di bagian Timur Laut dan Tenggara dari Kabupaten Mukomuko yaitu Kecamatan Selagan Raya, Teramang Jaya, Pondok Suguh, dan Air Rami masing-masing memiliki rata-rata kemiskinan yang tinggi. Sedangkan kecamatan dengan tingkat kemiskinan rendah adalah Kecamatan Lubuk Pinang.
\end{abstract}

Kata Kunci: Kemiskinan, Regresi Penalized Spline, Small Area Estimation, Kabupaten Mukomuko

\begin{abstract}
The main objective of this research is to map poverty level in Mukomuko district, Bengkulu Province. The method used in this study is small area estimation (SAE) using Penalized spline regression (P-Spline). In most cases, parameter estimation in SAE-based model establishes a linear mixed model which assumes that the response variable and the predictor variables have a linear relationship. When these assumptions are not met, nonparametric approaches can be used as an alternative option. One of them is the P-Spline nonparametric approach. This research utilizes P-Spline models to estimate parameter to obtain mixed effects regression as SAE model. Furthermore, the model is used to predict the level of poverty in the sample areas. Thus, the estimates of poverty at the village level in Mukomuko presented in poverty map is obtained. The results show that the estimator of poverty level using P-Spline model has a similar trend to the direct estimator. Sub-Districts with high poverty rate spread in the Northeast and Southeast parts of Mukomuko. The Sub-Districts are Selagan Raya, Teramang Jaya, Pondok Suguh, and Air Rami. Meanwhile, the Sub-District with lower poverty level is Lubuk Pinang.
\end{abstract}

Keywords: Poverty, Penalized Spline Regression, Small Area Estimation, Mukomuko District

\section{PENDAHULUAN}

Kemiskinan yang terjadi di Indonesia merupakan sebuah fenomena dan fakta yang menjadi salah satu masalah sosial yang sejak dulu hingga sekarang dan belum bisa teratasi baik oleh pemerintah pusat maupun oleh pemerintah daerah. Berdasarkan hasil survey Badan 
Pusat Statistik (BPS) pada bulan September 2012b, jumlah penduduk miskin (penduduk dengan pengeluaran per kapita per bulan di bawah Garis Kemiskinan) di Indonesia mencapai 28.59 juta orang (11.66 \%). BPS (September 2012b) mencatat bahwa Bengkulu menduduki peringkat dua terbawah provinsi termiskin di Sumatera yaitu sebesar $17.51 \%$ [1]. Menurut Kementerian Pembangunan Daerah Tertinggal dan BPS 2012, Bengkulu memiliki lima kabupaten tertinggal yang menyumbangkan proporsi penduduk miskin, salah satunya adalah Kabupaten Mukomuko. Penduduk miskin di Kabupaten Mukomuko sebanyak 21.6 ribu orang (13.21\%) [2].

Banyak program pengentasan kemiskinan yang telah dilakukan oleh pemerintah. Walaupun demikian, penurunan jumlah penduduk miskin dari tahun ke tahun terasa sangat lambat. Banyak faktor yang menyebabkan lambatnya laju pengurangan jumlah penduduk miskin, diantaranya adalah terbatasnya dana maupun ketidaktepatan program pengentasan kemiskinan. Usaha-usaha kedepan oleh pemerintah untuk mengurangi kemiskinan seyogyanya menggunakan pengembangan suatu program yang ditargetkan dan diarahkan untuk daerah yang paling terbelakang. Pendekatan ini dapat dilakukan untuk meningkatkan keefektifan biaya dari program intervensi sosial, yang implementasinya membutuhkan informasi tentang kemiskinan di tingkat lokal.

Pengukuran kemiskinan melalui sampel survei tidak dapat secara langsung menghasilkan ukuran kemiskinan pada tingkat agregasi yang rendah (misalnya kecamatan, desa/ kelurahan) karena adanya keterbatasan data. BPS melakukan analisis tingkat kemiskinan dalam Survey Sosial-Ekonomi Nasional (Susenas) setiap 2 tahun sekali. Pengumpulan data Susenas dilakukan dengan Cross sectional. Sampel yang terpilih merupakan data rumah tangga yang diambil sesuai blok sensus. Akibatnya statistik data tersebut memiliki presisi dan keakuratan yang kecil. Poverty mapping merupakan salah satu metode untuk mengukur dan memetakan kemiskinan suatu wilayah, salah satu poverty mapping yaitu dengan menggunakan Small Area Estimation (SAE). SAE merupakan suatu metode statistika untuk menduga parameter pada suatu subpopulasi dimana jumlah contohnya berukuran kecil atau bahkan tidak ada. Metode ini memanfaatkan data dari domain besar untuk menduga variabel yang menjadi perhatian pada domain yang lebih kecil [9].

SAE umumnya menggunakan pemodelan parametik untuk menghubungkan statistik area kecil dengan variabel-variabel pendukungnya. Pendugaan parameter model dasar SAE umumnya menggunakan metode EBLUP (Empirical Best Linear Unbiased Prediction) yang membangun suatu model linier campuran. Pemodelan ini kurang fleksibel dalam menyesuaikan dengan pola data hasil survei yang mungkin saja tidak mirip sama sekali dengan distribusi formal yang ada. Sehingga pendekatan nonparametrik menjadi alternatif pilihan. Salah satu pendekatan nonparametrik yang digunakan adalah Regresi Penalized Spline (P-Spline) [8].

Berbagai penelitian yang berkaitan dengan small area estimation dengan pendekatan nonparametrik telah banyak dilakukan antara lain Baskara (2014) menggunakan SAE dengan pendekatan P-Spline untuk menduga pengeluaran per kapita di Kabupaten Sumenep [3], Darsyah dan Iriyanto (2014) menggunakan SAE Kernel-Bootstrap untuk menduga tingkat kemiskinan di Indonesia [4], Darsyah (2013) menggunakan SAE Kernel-Bootstrap untuk menduga pengeluaran per kapita di Kabupaten Sumenep [5], Salvati et, al. (2009) menggunakan model nonparametrik based direct estimator [10], Opsomer et, al. (2008) mengembangkan SAE dengan pendekatan penalized spline regression [8].

Pada penelitian ini, dilakukan pendugaan tingkat kemiskinan pada desa sampel di Kabupaten Mukomuko dengan menggunakan metode SAE dengan pendekatan P-Spline. Sehingga diperoleh penduga tingkat kemiskinan untuk desa sampel di Kabupaten Mukomuko. Kemudian, hasil pendugaan akan disajikan dalam bentuk peta kemiskinan. Penelitian ini merupakan pengembangan dari penelitian yang pernah dilakukan mengenai SAE dan kemiskinan [7].

\section{KAJIAN LITERATUR}

\subsection{Small Area Estimation}

Small Area Estimation (SAE) merupakan suatu teknik statistika untuk menduga parameter-parameter subpopulasi yang ukuran sampelnya kecil atau bahkan area tidak tersampling. Di Indonesia, subpopulasi tersebut dapat berupa provinsi, kabupaten/ kota, kecamatan atau kelurahan/desa. SAE merupakan pendugaan tidak langsung yang mengkombinasikan antara data survei dengan data pendukung lain misalnya dari data Sensus 
sebelumnya yang memuat variabel dengan karakteristik yang sama dengan data survei sehingga dapat digunakan untuk menduga area yang lebih kecil dan memberikan tingkat akurasi lebih baik [9]

Dalam SAE terdapat dua jenis model dasar yang digunakan, yaitu model berbasis area dan model berbasis unit [9]. Pada model SAE berbasis area, data pendukung yang tersedia hanya sampai level area. Model level area menghubungkan penduga langsung area kecil dengan data pendukung dari domain lain untuk setiap area.

Parameter area kecil yang ingin diamati adalah $\theta_{i}$. Model linier yang menjelaskan hubungan tersebut adalah :

$\theta_{i}=x_{i}^{T} \beta+z_{i} v_{i}$

dengan $\beta=\left(\beta_{l}, \ldots, \beta_{p}\right)^{T}$ adalah koefisien regresi perukuran $p \times l, z_{i}=$ konstanta positif yang diketahui, $v_{i}=$ pengaruh acak area kecil, diasumsikan $v_{i} \sim$ iid $N\left(0, \sigma^{2}\right)$ dimana $i=1,2, \ldots, m$, dan $x_{i}^{T}$ adalah data pendukung area ke- $i$.

Dalam membuat kesimpulan tentang populasi diasumsikan bahwa nilai estimasi langsung $\hat{\theta}_{i}$ diketahui maka dapat dinyatakan sebagai berikut :

$\hat{\theta}_{i}=\theta_{i}+e_{i}$

dengan $e_{i}$ adalah sampling error, diasumsikan $e_{i} \sim \operatorname{iid} N\left(0, \psi_{i}\right)$ dan $i=1,2, \ldots, m$.

Model SAE untuk level area terdiri dari dua tingkat komponen model yaitu komponen model estimasi tidak langsung sesuai dengan persamaan (1) dan komponen model estimasi langsung sesuai persamaan (2). Model pada persamaan (1) dan (2) jika digabungkan membentuk persamaan sebagai berikut:

$\hat{\theta}_{i}=x_{i}^{T} \beta+z_{i} v_{i}+e_{i}$

dengan $i=1,2, \ldots, m$.

\subsection{Regresi Penalized Spline}

Regresi Penalized Spline atau P-spline adalah suatu metode smoothing yang sangat menarik karena mempunyai sifat sederhana, [6]. Diberikan model:

$y_{i}=m\left(x_{i}\right)+\varepsilon_{i}$

dimana $\varepsilon_{i}$ adalah peubah acak yang saling bebas dengan rataan $n p l$ dan varian $\sigma_{\varepsilon}^{2}$, Fungsi $m\left(x_{i}\right)$ adalah fungsi yang tidak diketahui dan diasumsikan dapat didekati dengan P-Spline:

$m\left(x_{i}\right)=\beta_{0}+\beta_{1} x+\ldots+\beta_{p} x^{p}+\sum_{j=1}^{K} \gamma_{j}\left(x_{i}-k_{j}\right)_{+}^{p}$

dengan $p$ adalah derajat spline (fixed), $\left(x_{i}-k_{j}\right)_{+}=\operatorname{maks}\left\{0,\left(x_{i}-k_{j}\right)\right\}, k_{j}, j=1, \ldots, K \quad$ adalah himpunan titik knot. $\boldsymbol{\beta}=\left(\beta_{0}, \ldots, \beta_{p}\right)^{T}$ merupakan vektor koefisien parametrik dari parameter yang tidak diketahui, $\boldsymbol{\gamma}=\left(\gamma_{1}, \ldots, \gamma_{k}\right)^{T}$ adalah vektor koefisien spline.

Misal diberikan $X=\left[\begin{array}{llll}1 & x_{i} & \ldots & x_{i}^{p}\end{array}\right]_{1 \leq i \leq n}, Z=\left[\left(x_{i}-k_{1}\right) \ldots\left(x_{i}-k_{K}\right)_{+}^{p}\right]_{1 \leq i \leq n}$,

dengan $\quad\left(x_{i}-k_{j}\right)_{+}^{p}= \begin{cases}\left(x_{i}-k_{j}\right)_{+}^{p} & \text { untuk } x_{i} \geq k_{j} \\ 0 & \text { untuk } x_{i}<k_{j}\end{cases}$

sehingga model persamaan (4) dapat ditulis dalam bentuk:

$y_{i}=\beta_{0}+\beta_{1} x+\ldots+\beta_{p} x^{p}+\sum_{j=1}^{K} \gamma_{j}\left(x_{i}-k_{j}\right)_{+}^{p}+e_{i}$

$\mathbf{Y}=\mathbf{X} \boldsymbol{\beta}+\mathbf{Z} \boldsymbol{\gamma}+\mathbf{e}$

dengan $\quad \mathbf{Y}=\left(y_{1} \ldots y_{n}\right)^{T}$

Persamaan (6) disebut sebagai model regresi spline smoothing. Fungsi spline pada model menunjukkan bahwa spline merupakan model polinomial terputus, tapi masih bersifat kontinu pada knot-knotnya [8]. 


\subsection{Small Area Estimation dengan Pendekatan Regresi P-Spline}

Misalkan terdapat $T$ area kecil, $U_{1}, U_{2}, \ldots, U_{T}$ adalah parameter yang akan diestimasi. Definisikan $d_{i t}=I_{\left\{i \in U_{T}\right\}}$ dan untuk setiap pengamatan $\mathbf{d}_{i}=\left(d_{i 1}, d_{i 2} \ldots, d_{i T}\right) . \mathbf{Y}=\left(y_{1}, y_{2}, \ldots, y_{n}\right)^{T}$, $\mathbf{X}=\left[\begin{array}{cccc}1 & x_{1} & \mathrm{~L} & x_{1}^{p} \\ \mathrm{M} & \mathrm{M} & 0 & \mathrm{M} \\ 1 & x_{n} & \mathrm{~L} & x_{n}^{p}\end{array}\right], Z=\left[\begin{array}{ccc}\left(x_{1}-k_{1}\right)_{+}^{p} & \mathrm{~L} & \left(x_{1}-k_{K}\right)_{+}^{p} \\ \mathrm{M} & 0 & \mathrm{M} \\ \left(x_{n}-k_{1}\right)_{+}^{p} & \mathrm{~L} & \left(x_{n}-k_{K}\right)_{+}^{p}\end{array}\right]$, dengan $\left(x_{i}-k_{j}\right)_{+}^{p}=\left\{\begin{array}{lr}\left(x_{i}-k_{j}\right)_{+}^{p} & \text { untuk } x_{i} \geq k_{j} \\ 0 & \text { untuk } x_{i}<k_{j}\end{array}\right.$

Opsomer (2008) menggunakan P-Spline untuk mengestimasi area kecil dengan menambahkan pengaruh acak area kecil pada persamaan (7), sehingga diperoleh [8]:

$\mathbf{Y}=\mathbf{X} \boldsymbol{\beta}+\mathbf{Z} \boldsymbol{\gamma}+\mathbf{D} \mathbf{u}+e$

dengan $\mathbf{X} \boldsymbol{\beta}+\mathbf{Z} \boldsymbol{\gamma}$ adalah fungsi nonparametrik spline, Du adalah pengaruh acak area kecil, $\mathbf{D}=\left(d_{1}, \ldots, d_{n}\right)^{T}$ adalah matriks covarian, dan $\mathbf{u}$ adalah vektor pengaruh area kecil, setiap komponen acak diasumsikan independen satu sama lain, dan

$\gamma:\left(\mathbf{0}, \Sigma_{\gamma}\right), \Sigma_{\gamma} \equiv \sigma_{\gamma}^{2} I_{K}$

$\gamma:\left(\mathbf{0}, \Sigma_{u}\right), \Sigma_{u} \equiv \sigma_{u}^{2} I_{T}$

$\gamma:\left(\mathbf{0}, \Sigma_{\varepsilon}\right), \Sigma_{\varepsilon} \equiv \sigma_{\varepsilon}^{2} I_{n}$

Jika komponen ragam diketahui, pendugaan pengaruh tetap $\boldsymbol{\beta}$ dapat dilakukan dengan metode Maximum Likelihood Estimation (MLE) dengan menganggap $\gamma$ dan $u$ sebagai pengaruh acak. Persamaan (7) dapat ditulis menjadi (9):

$\mathbf{Y}=\mathbf{X} \boldsymbol{\beta}+\boldsymbol{\varepsilon}^{*}$

dengan $\boldsymbol{\varepsilon}^{*}=\mathbf{Z} \boldsymbol{\gamma}+\mathbf{D u}+e$

Penduga parameter $\boldsymbol{\beta}$ dapat diperoleh dengan memaksimumkan fungsi likelihoodnya sehingga diperoleh:

$\hat{\boldsymbol{\beta}}=\left(\mathbf{X}^{\mathrm{T}} \mathbf{V}^{-1} \mathbf{X}\right)^{-1} \mathbf{X}^{\mathrm{T}} \mathbf{V}^{-1} \mathbf{Y}$

dengan $\mathbf{V}=\mathbf{Z} \sum_{\gamma} \mathbf{Z}^{\mathbf{T}}+\mathbf{D} \sum_{\mathbf{u}} \mathbf{D}^{\mathbf{T}}+\sum_{\mathbf{e}}$ adalah matriks varian covarian dari $\mathbf{Y}$.

Penduga terbaik untuk variabel prediktor $\gamma$ dan $u$ diperoleh dengan meminimumkan MSE dari $\gamma$ dan $u$. Sehingga diperoleh prediktor linier tak bias terbaik (BLUP) untuk $\gamma$ dan $u$ sebagai berikut:

$\hat{\gamma}=\sum_{\gamma} \mathbf{Z}^{T} \mathbf{V}^{-1}(\mathbf{Y}-\mathbf{X} \hat{\boldsymbol{\beta}})$
$\hat{u}=\sum_{u} \mathbf{Z}^{T} \mathbf{V}^{-1}(\mathbf{Y}-\mathbf{X} \hat{\boldsymbol{\beta}})$

Untuk area kecil $U_{T}$ yang diberikan, maka akan dilakukan pendugaan terhadap:

$\bar{y}_{t}=\bar{x}_{t} \beta+\bar{z}_{t} \gamma+u_{t}$

dimana $\bar{x}_{\mathbf{t}}$ adalah nilai rata-rata dari $x_{i}, \bar{z}_{\mathbf{t}}$ adalah basis fungsi spline, dan $u_{t}$ adalah pengaruh acak area kecil dengan $u_{t}=\mathbf{d}_{\mathbf{t}} \mathbf{u}=\mathbf{e}_{\mathbf{t}} \mathbf{u}$, dan $\mathbf{e}_{\mathbf{t}}$ adalah vektor dengan nilai 1 saat ke-t, dan bernilai 0 untuk $t$ lainnya sehingga penduga untuk $\bar{y}_{t}$ yaitu:

$\hat{y}_{t}=\bar{x}_{t} \hat{\beta}+\bar{z}_{t} \hat{\gamma}+\mathbf{e}_{\mathbf{t}} \hat{u}_{t}$

yang merupakan kombinasi linier penduga GLS pada (10) dan BLUP pada (11) dan (12), sehingga $\hat{y}_{t}$ merupakan BLUP untuk $\bar{y}_{t}$. 


\section{METODE PENELITIAN}

Penelitian ini menggunakan data sekunder yang diperoleh dari Badan Pusat Statistika Provinsi Bengkulu (Data Susenas dan Podes 2014). Objek penelitian adalah desa yang menjadi sampel pada Susenas 2014 di Kabupaten Mukomuko Provinsi Bengkulu. Adapun variabel yang digunakan dalam penelitian meliputi:

1. Variabel respon $(\mathrm{Y})$ : Rata-rata pengeluaran perkapita

2. Variabel prediktor:

- Jumlah Keluarga Tanpa Listrik $\left(\mathrm{X}_{1}\right)$

- Sumber Air Bersih $\left(\mathrm{X}_{2}\right)$

- Jumlah Sarana Pendidikan $\left(\mathrm{X}_{3}\right)$

- Jumlah Sarana Kesehatan $\left(\mathrm{X}_{4}\right)$

- Jumlah Penderita Gizi Buruk $\left(\mathrm{X}_{5}\right)$

- Jumlah Penerima Jamkesmas $\left(\mathrm{X}_{6}\right)$

- Jumlah SKTM $\left(\mathrm{X}_{7}\right)$

Langkah-langkah yang dilakukan dalam penelitian sebagai berikut:

1. Melakukan Eksplorasi Data

2. Teknik Analisis Data

Teknik analisis data dilakukan dengan menggunakan SAE dengan pendekatan Regresi Penalized Spline. Analisis dilakukan dengan bantuan paket program $R$. Adapun langkahlangkah dalam analisis data adalah:

1. Membuat scatter plot antara variabel respon dan variabel prediktor

2. Menentukan jumlah dan lokasi titik knot berdasarkan nilai GCV optimum

3. Melakukan pendugaan pengaruh tetap $\boldsymbol{\beta}$ untuk model P-Spline terbaik

4. Melakukan pendugaan variabel respon berdasarkan hasil estimasi model

5. Menentukan korelasi model pendugaan dengan variabel respon

6. Menghitung nilai AIC sebagai kriteria pemilihan model terbaik

3. Membuat peta kemiskinan di Kabupaten Mukomuko dengan terlebih dahulu menentukan hotspot kemiskinan menggunakan GIS (Geographic Information System).

Peta kemiskinan dapat disusun setelah peneliti mengetahui tingkat kemiskinan di suatu area. Peta ini dapat digunakan untuk memberikan beberapa rekomendasi terkait dengan proses perencanaan dan penyelenggaraan program pengentasan kemiskinan.

\section{HASIL DAN PEMBAHASAN}

Berdasarkan survei SUSENAS 2014, terdapat 45 desa yang menjadi sampel dalam pendugaan rata-rata pengeluaran perkapita perbulan untuk level desa di Kabupaten Mukomuko. Sehingga pada penelitian ini, akan dilakukan pendugaan area kecil untuk 45 desa dengan menggunakan pendekatan regresi penalized spline. Eksplorasi data pengeluaran perkapita pada level desa di Kabupaten Mukomuko dapat dilihat pada Tabel 1.

Pada Tabel 1. dapat dilihat rataan dari rata-rata pengeluaran perkapita di Kabupaten Mukomuko tahun 2014 sebesar Rp. 761992.11. Sekitar 75\% desa-desa di Kabupaten Mukomuko memiliki rata-rata pengeluaran perkapita sebesar Rp 853921.36 dan 25\% sebesar Rp 581008.07. Rata-rata pengeluaran perkapita terbesar berada di Desa Lubuk Pinang sebesar Rp. 1402866.03 dan terendah berasal dari Desa Bandar Jaya (Rp 367360.24).

Tabel 1. Rata-rata Pengeluaran Perkapita di Kabupaten Mukomuko Tahun 2014

\begin{tabular}{lr}
\hline Statistik & Pengeluaran Perkapita/ Bulan (Rp) \\
\hline Rata-rata & 761992.11 \\
Kuartil ke-1 & 581008.07 \\
Kuartil ke-3 & 853921.36 \\
\hline
\end{tabular}




\subsection{Pemodelan Kemiskinan di Kabupaten Mukomuko Menggunakan SAE dengan Pendekatan P-Spline}

Pola sebaran data antara rata-rata pengeluaran perkapita sebagai variabel respon dengan setiap variabel prediktor tidak membentuk suatu pola tertentu, dimana persebaran datanya bergerombol sehingga tidak memenuhi asumsi model SAE. Berdasarkan hal tersebut, pada penelitian ini akan dilakukan pendugaan model SAE dengan pendekatan nonparametrik PSpline. Berdasarkan proses analisis data, nilai GCV optimum diperoleh dari model P-Spline linier dengan 1 titik knot. sehingga model yang digunakan untuk memodelkan kemiskinan berdasarkan rata-rata pengeluaran perkapita pada desa sampel di Kabupaten Mukomuko adalah model P-Spline linier dengan satu titik knot. Nilai penduga $\beta$ untuk model P-Spline terbaik (spline linier dengan 1 knot) maka diperoleh penduga model sebagai berikut:

$$
\begin{aligned}
\mathbf{Y}= & 528494.92-227.72 \mathbf{X}_{1}+12532.04 \mathbf{X}_{2}-973.92 \mathbf{X}_{3}+21399.44 \mathbf{X}_{4}+62518.11 \mathbf{X}_{5}+ \\
& 482.42 \mathbf{X}_{6}+438.94 \mathbf{X}_{7}+\gamma_{1}\left(\mathbf{X}_{1}-31.17\right)_{+}^{1}+\gamma_{2}\left(\mathbf{X}_{2}-3\right)_{+}^{1}+\gamma_{3}\left(\mathbf{X}_{3}-9.99\right)_{+}^{1}+ \\
& \gamma_{4}\left(\mathbf{X}_{4}-3.5\right)_{+}^{1}+\gamma_{5}\left(\mathbf{X}_{5}-0.99\right)_{+}^{1}+\gamma_{6}\left(\mathbf{X}_{6}-3.02\right)_{+}^{1}+\gamma_{7}\left(\mathbf{X}_{7}-2.02\right)_{+}^{1}+u
\end{aligned}
$$

dengan nilai penduga pengaruh acak $\hat{\gamma}_{i}$ dan $\hat{u}$ bergantung pada masing-masing area.

\subsection{Penduga Kemiskinan di Kabupaten Mukomuko Berdasarkan Model SAE dengan P-Spline}

Berdasarkan Tabel 2, hasil pendugaan rata-rata pengeluaran perkapita pada level desa di Kabupaten Mukomuko tahun 2014 dengan menggunakan model SAE dengan P-Spline sebesar Rp. 765441.88. Sekitar 75\% desa-desa di Kabupaten Mukomuko memiliki rata-rata pengeluaran perkapita sebesar $\mathrm{Rp} 855254.66$ dan 25\% sebesar $\mathrm{Rp}$ 631398.85. Rata-rata pengeluaran perkapita terbesar berada di Desa Lubuk Pinang sebesar Rp. 1113282.57 dan terendah berasal dari Desa Bandar Jaya (Rp 391894.60).

Tabel 2. Pendugaan Rata-Rata Pengeluaran Perkapita Kabupaten Mukomuko dengan Model SAE P-Spline

\begin{tabular}{lr}
\hline Statistik & Pengeluaran Perkapita/ Bulan (Rp) \\
\hline Rata-rata & 765441.88 \\
Kuartil ke-1 & 631398.85 \\
Kuartil ke-3 & 855254.66 \\
\hline
\end{tabular}

Perbandingan penduga langsung dan penduga P-Spline terhadap rata-rata pengeluaran perkapita pada masing-masing desa di Kabupaten Mukomuko dapat dilihat pada Gambar 2.

Dari Gambar 2 dapat dilihat bahwa hasil pendugaan menggunakan model SAE dengan PSpline memiliki trend (kecendrungan) yang sama dengan penduga langsung. Artinya bahwa, kedua metode tersebut mengindikasikan pendugaan menghasilkan penduga yang konsisten. Meskipun ada beberapa desa sampel mempunyai trend yang tidak sama yang dicurigai sebagai data pencilan karena karena rata-rata pengeluaran perkapita jauh melebihi nilai untuk desa lainnya. 


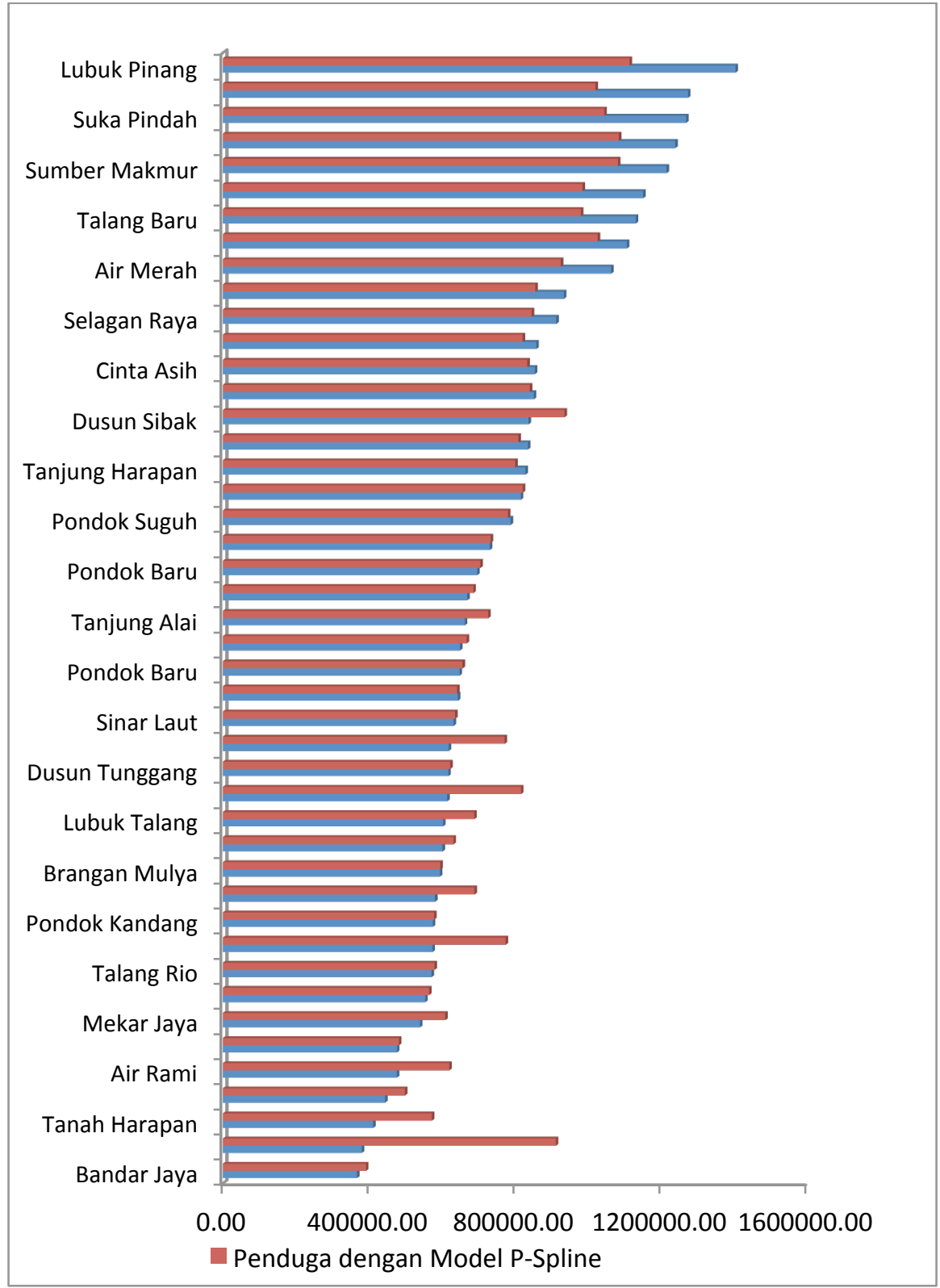

Gambar 1. Perbandingan Penduga Langsung dengan Penduga P-Spline

\subsection{Peta Kemiskinan Kabupaten Mukomuko}

Peta kemiskinan Kabupaten Mukomuko berdasarkan hasil pendugaan rata-rata pengeluaran perkapita untuk 45 desa sampel dapat dilihat pada Gambar 2. Dari 15 kecamatan yang ada di Kabupaten Mukomuko, terdapat 9 kecamatan yang tingkat kemiskinannya dapat dipetakan, sedangkan 6 kecamatan lainnya belum dapat dilakukan pemetaan kemiskinan karena tidak ada desa yang menjadi sampel penelitian. Pada peta ini, warna polygon kecamatan yang tidak termasuk dalam sampel diberi warna hijau tosca dan warna polygon kecamatan yang menjadi sampel diberi warna ungu dengan gradasi sesuai tingkat kemiskinannya.

Kecamatan dengan rata-rata pengeluaran perkapita rendah yang mengindikasikan tingginya tingkat kemiskinan memiliki polygon berwarna ungu muda. Berdasarkan pada Gambar 2 terlihat bahwa kecamatan yang memiliki tingkat kemiskinan tinggi menyebar di bagian Timur Laut dan Tenggara dari Kabupaten Mukomuko yaitu Kecamatan Selagan Raya, Teramang Jaya, Pondok Suguh, dan Air Rami memiliki rata-rata kemiskinan yang tinggi. Sedangkan kecamatan dengan tingkat kemiskinan rendah adalah Kecamatan Lubuk Pinang. 


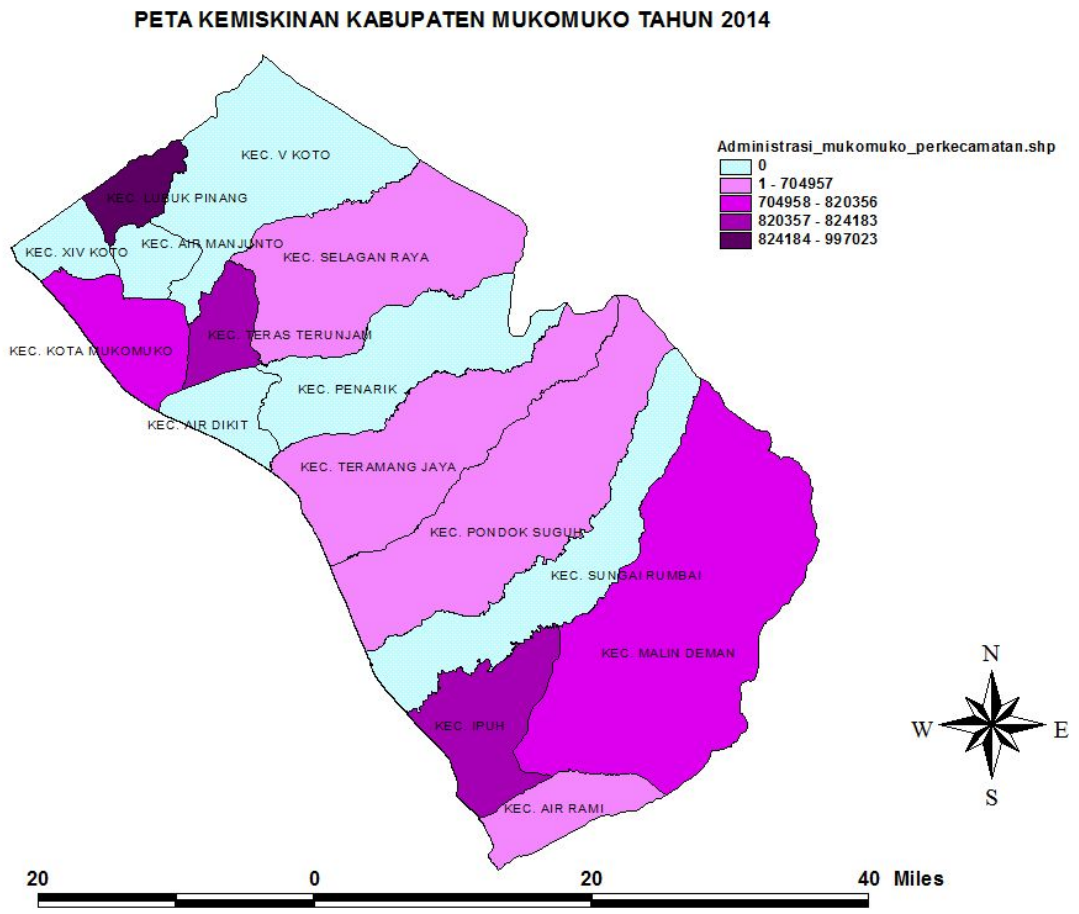

Gambar 2. Peta Kemiskinan Kabupaten Mukomuko

\section{KESIMPULAN}

Small area estimation (SAE) dengan pendekatan regresi penalized spline (P-Spline) dapat digunakan untuk pemetaan kemiskinan berdasarkan pendugaan rata-rata pengeluaran perkapita pada level desa di Kabupatan Mukomuko. Hasil pendugaan menggunakan model SAE dengan P-Spline memiliki trend (kecendrungan) yang sama dengan penduga langsung.

Hasil pendugaan rata-rata pengeluaran perkapita pada level desa di Kabupaten Mukomuko tahun 2014 dengan menggunakan model SAE dengan P-Spline sebesar Rp. 765441.88. Sekitar 75\% desa-desa di Kabupaten Mukomuko memiliki rata-rata pengeluaran perkapita sebesar Rp 855254.66 dan 25\% sebesar Rp 631398.85. Rata-rata pengeluaran perkapita terbesar berada di Desa Lubuk Pinang sebesar Rp. 1113282.57 dan terendah berasal dari Desa Bandar Jaya (Rp 391894.60).

Kecamatan yang memiliki tingkat kemiskinan tinggi menyebar di bagian Timur Laut dan Tenggara dari Kabupaten Mukomuko yaitu Kecamatan Selagan Raya, Teramang Jaya, Pondok Suguh, dan Air Rami memiliki rata-rata kemiskinan yang tinggi. Sedangkan kecamatan dengan tingkat kemiskinan rendah adalah Kecamatan Lubuk Pinang.

\section{UCAPAN TERIMAKASIH}

Ucapan terimakasih peneliti sampaikan kepada pihak-pihak yang telah membantu dalam penyelesaian penelitian ini. Ucapan terimakasih juga peneliti sampaikan kepada FMIPA Universitas Bengkulu yang telah mendanai penelitian ini melalui dana PNBP FMIPA Universitas Bengkulu Tahun 2016.

\section{DAFTAR PUSTAKA}

[1] BPS.2012a. Berita Resmi Statistik-Profil Kemiskinan di Indonesia September 2012. No. 06/01/Th. XVI, 2 Januari 2013.

[2] BPS. 2012b. Data Strategis BPS. Katalog BPS 1103003, No. 03220.1202. ISSN. 2087-2011. 
[3] Baskara ZW, Rumiati AT. 2014. Pendugaan Area Kecil Menggunakan Pendekatan Penalized Spline [tesis]. Program Pascasarjana, Institut Teknologi Sepuluh Nopember, Surabaya.

[4] Darsyah MY, Iriyanto S. 2014. Analysis of Poverty in Indonesia with Small Area Estimation: Case ini Demak District. South East Asia Journal of Contemporary Business, Economics and Law, Vol. 5, Issue 3, Hal. 18-23.

[5] Darsyah MY. 2013. Small Area Estimation terhadap Pengeluaran Per Kapita di Kabupaten Sumenep dengan pendekatan Kernel-Bootstrap. Jurnal Statistik UNIMUS, Vol.1 No.2, November, Hal. 28-36.

[6] Eilers PHC, Marx BD. 1996. Flexible smoothing with B-splines and penalties. Statist. Sci., 1996, Vol. 11, Hal. 89-121.

[7] Etis S, Novianti P, Sriliana I, Agustina D. 2014. Estimasi Tingkat Kemiskinan Pada Level Desa Di Kabupaten Mukomuko Dengan Menggunakan Small Area Estimation. Prosiding Seminar Nasional Bidang Ilmu MIPA SEMIRATA, Universitas Tanjung Pura, Pontianak. Hal. 363-371.

[8] Opsomer DJ, Claeskens G, Ranalli MG, Kauermann G, Breidt FJ. 2008. Non-parametric Small Area Estimation Using Penalized Spline Regression. Royal Statistical Society Journal. 2008, Vol.70, Part 1, Hal. 265-286.

[9] Rao JNK. 2003. Small area estimation. Wiley, London.

[10] Salvati N, Chandra H, Ranalli MG, Chambers R. 2008. Small Area Estimation Using a Nonparametric Model Based Direct Estimator. Centre for Statistical \& Survey Methodology, University of Wollongong, Wollongong NSW. 